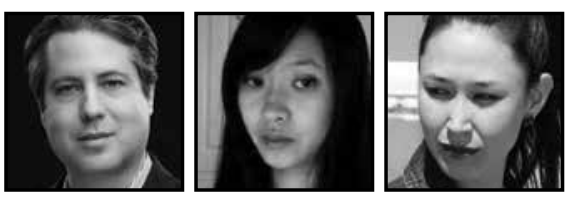

\title{
Researching From Buried Experiences: Collaborative Inquiry With Asian American Youth
}

\author{
Gerald Campano, Lan Ngo, and Grace Player, \\ University of Pennsylvania
}

\begin{abstract}
This article reports on an out-of-school practitioner researcher study, the Community Researchers Project, involving predominately Indonesian youth who were members of a Catholic parish in a diverse multilingual neighborhood of our city. The lives and learning of many of the youth in the Indonesian immigrant community were, to a large extent, invisible in the research literature or homogenized through broader generalizations regarding Asian Americans, such as the myth of the "model minority." Through analysis of several representative student inquiries, we argue that practitioner research can be an effective methodological vehicle for unearthing "buried" personal and collective histories that impact students.
\end{abstract}

Lan: What did you learn while you were doing your research?

Brian: I learned that there was two types of diabetes. One is Type 2 Diabetes and one was Type 1 Diabetes, and um I thought diabetes was like one disease, but there was like two disease in there, and um I was scared for my mom and dad because both of them have diabetes, but I didn't know what type they had diabetes, and um both of them didn't know, too. So um I think that tomorrow we're going to have an appointment to tell them like - to tell the doctors what diabetes they kind of have. [Interview, Jul. 20, 2014] 
n an interview, Brian (all names are pseudonyms) describes findings from the diabetes research he conducted while participating in an out-of-school teacher researcher study, what we call the Community Researchers Project (CRP), involving predominately Indonesian youth who were all members of a Catholic Parish in a diverse multilingual neighborhood of our city. The CRP was part of an ongoing research partnership with our university team that supports immigrant families and students in their efforts to acquire educational opportunities (Ghiso \& Campano, 2013). The authors, along with two other members of the research team, designed and taught a collaborative inquiry with 13 youth, ages 10-14. The youth analyzed high-quality nonfiction books with social justice themes to study how data are represented in texts. Inspired by these books, they then learned qualitative research skills to investigate issues that were relevant to their own lives. They collected evidence on their topics from primary data sources and created their own multimodal representations of their findings, which they shared with their families and community leaders in a culminating poster presentation. The youth also presented their work during Practitioner Research Day at the annual Ethnography in Education Research Forum at the University of Pennsylvania. As teacher researchers, we strived to nurture a space for student inquiry while pursuing our own emerging questions on our practice.

The youth chose a range of topics to investigate, including the state of the public education system in the city, the nature of friendship, and the role of graffiti in urban spaces. Brian was one of several participants who, unpredicted by us, became interested in researching the medical field and diseases. We initially speculated that one reason this might have become a popular topic among the youth researchers is that medicine is considered a prestigious area of study for ambitious middle school students, an aspiration perhaps sanctioned by their parents. This explanation would certainly conform to "model minority" stereotypes and other prevalent assumptions regarding Asian American students that position them as excelling academically (Lee, 2009). Adopting an inquiry stance into our practice (Cochran-Smith \& Lytle, 2009), however, led us to question our initial assumptions and situate teaching and learning within its larger social, cultural, and political contexts, thus enabling us to notice other motivations for the students' research interests percolating beneath these stereotypes. Brian, like several of his peers, witnessed first-hand how family members struggled to gain access to adequate health care. Through our research, we would come to learn how a variety of interrelated factors - such as language difference, citizenship status, poverty, and bullying (see Campano, Ghiso, Yee, \& Pantoja, 2013)—might coalesce to inhibit immigrant families from procuring basic social goods and services. Brian was interested in medicine not simply for its prestige, but also because he desired better and more socially just opportunities for his loved ones and community, what might be 
characterized as an ethos of care and interdependence (Ghiso, in press). This desire and sense of advocacy is evident in the immediate urgency he feels to go with his parents to an appointment "tomorrow" to identify the types of diabetes they might have.

In this article, we document how teacher research became a methodological vehicle through which to learn from youth about the issues of inequity and vulnerability they face in their daily lives. We also learned about their agency, the ways in which they could interpret these experiences and work toward change. It is important to note that these are not necessarily things we could have learned through reading secondary sources or studies. As we describe in the section that follows, the lives and learning of many of the youth in the Indonesian immigrant community were, to a large extent, invisible in the research literature or homogenized through broader generalizations regarding Asian Americans. In the absence of codified research literature that accurately reflected their lived experiences, the youth themselves became the experts on their communities. Practitioner research helped create a space for students to research and represent their own subaltern experiences, potentially making the issues that matter to them visible to larger audiences.

\section{Asian Americans and Indonesian Americans}

The misconception that Asian Americans are all the same "[masks] the complexity and diversity that exist within each racial population" (Museus \& Kiang, 2009, p. 7). Within the field of education, Asian American youth are beholden to the myth of the model minority. This stereotype characterizes the experiences of Asian Americans as marked by economic prosperity, educational attainment, and upward social mobility. As a result, Asian Americans are often not included in the definition of underrepresented racial or ethnic minorities according to private and public funding agencies, with the implication that Asian Americans do not require attention and support (Museus \& Kiang, 2009). Even our own institution does not consider Asian Americans an underrepresented minority. In their review of the literature on Southeast Asian American education, Bic Ngo and Stacey J. Lee (2007) draw on research by Hune (2000) and Lowe (1996) to conclude that there is a need for studies that "challenge assumptions of a universal experience within and across groups" (p. 442). This critique underscores how many of the diverse experiences of Asian Americans remain invisible in the educational literature. 
The tradition of practitioner research from which we draw underscores how our own positionalities might productively inform our stance as researchers. We invariably bring our own experiences and cultural identities into our research, and our methodological orientation invites self-reflexivity about these hermeneutic horizons (Alcoff, 2006). Our own personal and familial histories made us aware of experiences buried beneath dominant narratives of immigration and Asian-American identity. Gerald, who is of mixed ethnicity, learned from his grandfather, a Filipino migrant laborer who arrived to the United States in the 1920s, about the virulent racism and legalized discrimination his generation endured, including anti-miscegenation laws and prohibitions to property ownership. This history was not in Gerald's school textbooks. Growing up, Lan did not identify with the portrayals of Chinese Americans in media and literature. Though her family is ethnically Chinese, her parents and brother migrated from Vietnam, their home country, at the end of the Vietnam (or "American") War, and her other brother was born in Hong Kong just before their arrival to the U.S. These transnational border crossings and perspectives are often lost within the label "Asian-American." Grace is the daughter of an Asian-Latina. Only through her mother's stories did she learn of her family's flight from Japan to Brazil before World War II and the subsequent racism she faced as a linguistic and ethnic minority in both her home country and in the United States. Grace's school experiences failed to acknowledge the existence of Asian Latina/os.

Our own backgrounds sensitized us to how contemporary Asian-American youth might have similar buried experiences and fueled our desire to do research that more accurately honored them. The group of Indonesian-American youth with whom we have been working for the past year and a half helped us better understand the minoritized and racialized nature of their immigrant identities, which may be too often overlooked by researchers and practitioners alike. According to the U.S. 2010 census, 63,383 people reported Indonesian and "one detailed Asian group" as their ethnic identification, and 6,713 reported Indonesian and "two or more detailed Asian groups" for a total U.S. population of 70,096 (U.S. Census Bureau, 2012). The latter are likely nearly all Indonesian Chinese, but this cannot be confirmed (as informed by Cunningham, 2008). The obscurity resulting from official data collection is also evidenced in the American Community Survey 5-Year Estimates (U.S. Census Bureau, 2011), which only includes groups with more than 4,000 persons in a city. As such, information about Indonesians in the city of this research study, for example, is largely missing.

After conducting research on Indonesian migrants to the U.S., Cunningham (2008) surmised that about 25,000 Indonesians were of undocumented immigration status and thus not taken into account in census data. In the late 1980s and 1990s, Indonesians of Chinese descent and those that were Christian "suffered from discrimination, 
sporadic violence, and threat of danger in the homeland that encouraged some people to migrate to Australia, Singapore, the United States, and Canada" (p. 90). Despite this oppression, they did not arrive to their host country with government-sanctioned refugee status, and once in the United States, they encountered precarious social standing (Cunningham, 2008). For example, the Commonwealth of Pennsylvania alone ordered approximately 2,400 people deported to Indonesia between 2002-2012 (Asian Americans Advancing Justice, 2013). Over the years at our research site, many Indonesian families have been torn apart and the educational possibilities for many youth have become constrained. At the same time, the community has organized to challenge anti-immigration sentiments and support more expansive educational opportunities. In fact, it was the desire of Indonesian families for educational opportunities that was the basis for our collaborative research with the youth.

\section{Viewing Immigrant Youth as Cosmopolitan Intellectuals Through Practitioner Research}

Despite their current struggles in the U.S., the Indonesian community has rich intellectual and activist legacies. Unlike the characterization of model minorities who are lauded for their perceived facility to assimilate into the dominant culture, the students and their families might better be thought of as cosmopolitan intellectuals (Campano \& Ghiso, 2011) who draw from their transnational experiences to navigate multiple contexts and analyze social inequities through a comparative framework. As cosmopolitan intellectuals, students may mobilize their language and literacy practices to "articulate buried histories, enlarge our aesthetic sensibilities, redraw boundaries, rethink what it means to be an American, and cultivate human rights commitments that transcend national borders" (p. 175). The concept of buried pasts has been a foundational trope in Asian-American studies (Ichioka, 1974; Lee, 2014). It signifies those histories and experiences that are absent in the codified historical or institutional record. Our work with the youth sought to create a curricular space for students to mobilize their identities and rich cultural resources to research their own buried experiences into existence.

Teacher/Practitioner research as a theoretical and methodological orientation is uniquely suited for these inquiries. In our description of these frameworks, we follow Cochran-Smith and Lytle's $(1993,2009)$ shift in terminology from "teacher research" to "practitioner research" in order to underscore that educators in a range of positions have a practice to investigate, including ourselves as university partners with the St. Frances Cabrini community and as facilitators of the inquiry we report on in this article. One key feature of practitioner research is that it challenges established hierarchies of 
knowledge. As Cochran-Smith and Lytle (2009) argue, in practitioner research, rather than content being static, pre-determined, and transmitted to students,

subject-matter knowledge is fluid and dynamic, constructed in the interactions of all participants within learning communities; part of what it means to learn subject matter, then, is to critique its meanings and sources, including whose knowledge perspectives are left out. (p. 2)

In interrogating the relationship between knowledge and power, a practitioner research orientation has a social justice dimension. One request from the parents of the youth in the Community Researcher's Project was to support their children with the Common Core State Standards (CCSS), a new curricular emphasis in their schools. The CCSS emphasize the importance of engaging students with high-level nonfiction texts. One of the dilemmas for us as practitioner researchers was that there were very few high-quality nonfiction texts that represent the histories of Asian Americans, much less a minoritized group like the Indonesian community. In past research, Gerald had grappled with this issue by conceptualizing students' testimonials as a form of subaltern history that may be incorporated in the literacy curriculum (Campano, 2007a, 2007b). In some iterations of the CCSS, however, there is an explicit devaluation of personal narrative in favor of staying within the confines of the published nonfiction text. We conceptualized our practitioner research study as working within and against these parameters: introducing the Indonesian youth to a number of informational texts as well as to qualitative research methods, and then inviting students to carry out and represent their own inquiries on topics that mattered to them. In this way, we were able to support families in their concern that the youth meet the standards while at the same time enacting a critical, culturally responsive pedagogy (Gay, 2014) that honors the inquiries of the students themselves.

Another key feature of practitioner research is that it views dissonance as an opportunity for further learning and inquiry. Teacher researcher Ballenger (2009) uses the term "puzzling moments" to describe how educators might respond to, for example, moments when instruction did not go as planned, or when students appeared to not understand a lesson, text, or conceptual point. Rather than immediately dismiss the children as incorrect, the teachers in her inquiry group learned to pause and puzzle over these moments, from the perspective that the children were rational sense-makers. Through practitioner research, the dissonance between a teacher's expectations and the actual responses of students can be mined for further learning, in an ever-evolving process of theorizing one's practice (Campano, 2009). Vivian Vasquez's (2004) teacher research with diverse young children in Canada emphasizes the possibilities of following 
students' leads in the curriculum, including their emerging sense of unfairness and injustice. In line with this tradition, our stance as practitioner researchers, then, involves taking seriously the sense-making and agency of the young people with whom we work. In our study, one of the dissonances concerned how the topics the youth chose to write about didn't conform to our expectations, prompting us to more deeply inquire into their scholarly interests and claims.

\section{Context and Design of the Study}

This article focuses on one inquiry within our broader research partnership with St. Frances Cabrini. The multicultural and multilingual parish provides a communal gathering place for immigrants from Vietnam, Indonesia, the Philippines, and Latin America, as well as its long-standing Italian-American and African-American congregations. St. Frances Cabrini strives to value the perspectives, language, and traditions of the different cultural groups and provide opportunities to work together in the service of social justice. Our research explores how individuals use language and literacy across social, cultural, linguistic, and institutional boundaries to negotiate a shared vision of educational justice and immigrant rights.

Our overall partnership with the St. Frances Cabrini parish, school, and community center combines traditional ethnographic methods (Erickson, 1986) with practitioner research (Cochran-Smith \& Lytle, 2009). We seek to involve community members throughout the research process, striving toward collaboration and transparency in our methodology (Campano, Ghiso, \& Welch, 2015). The St. Frances Cabrini children and families, including the Indonesian youth who were part of the Community Researchers Project, have epistemic privilege-or knowledge derived from minoritized social locations (Campano, 2007a; Moya, 2002)—which situates them as uniquely positioned to analyze social inequities and power asymmetries. As practitioner researchers, we sought to redistribute intellectual authority by valuing the perspectives of youth and community members themselves.

The Community Researchers Project, ${ }^{1}$ a year-and-a-half-long inquiry nested within this larger partnership, investigated the following research questions:

- What happens when we invite immigrant youth to connect their own experiences and interests to the study of nonfiction?

- What do we learn from the students' research and their multimodal representations? 
The 13 participating youth, ages 10-14, met every other weekend between Fall 2013 and Spring 2015. Eleven of the students were from the Indonesian community and two were from the Latina/o community at St. Frances Cabrini. Some students were immigrants themselves, and others were second generation. Among the Indonesian population, most had Chinese heritage, making them and/or their families ethnic minorities not just in the United States, but also in Indonesia. Youth were recruited by community leaders, who had helped co-design the program and took responsibility for publicizing it. Any student between grades five and nine in the St. Frances Cabrini community who was interested in the program was eligible to participate.

The curriculum for the Community Researchers Project was designed by our university research team in concert with community leaders, particularly the mother of one of the youth participants. It invited youth to view their experiences as sources of knowledge-experiences that are buried by most nonfiction accounts of American history and by the reified categories and stereotypes of Asian Americans. We began by drafting an outline of the curriculum, which we shared with a community representative to ensure that our goals were aligned. While a general trajectory was laid out before implementation, we adhered to an inquiry model whereby we continually modified and reimagined the curriculum based on what we were learning from the youth in order to build on their talents, knowledge, and inquiries. We also embraced feedback from community leaders and the director of the St. Frances Cabrini Center. The initial sessions supported the youth in examining nonfiction books. They spent time reading, discussing, and sharing the high-quality texts we had purchased for the project, including selections from the Notable Books for a Global Society selected annually by the Children's Literature and Reading Special Interest Group of the International Reading Association. We promoted critical readings of the texts through discussions concerning notions of truth, perspective, authorship, and audience. The students also explored textual and graphic presentation of information, adjudicating the affordances and limitations of each mode.

The inquiry into nonfiction texts provided a foundation for the CRP youth to think about their own research projects and how to eventually represent their findings. They discussed concepts such as "research," "community," and "social justice" and thought about their membership in various communities to brainstorm potential lines of inquiry. As the youth settled on research questions they wanted to pursue, we introduced and critically engaged various research methods, such as interviews, fieldnotes, and surveys. CRP youth gathered data on their topics and spent time interpreting their findings with peers. They then decided on the best modes to convey 
their findings and created their own nonfiction texts, which would be shared with wider audiences at St. Frances Cabrini and beyond.

Data sources for our study consisted of detailed fieldnotes of inquiry group sessions, artifacts (e.g., student work produced during the sessions), nine audio-recorded interviews with inquiry group participants, and researcher reflective memos. Interviews were an average length of 16 minutes, and ranged from 8 to 25 minutes; due to the age of the participants, we found shorter interviews more suitable. Data was analyzed thematically in a recursive and iterative process (Strauss \& Corbin, 1998) to understand the issues youth deemed significant and the intersecting factors that shaped their lives and learning.

\section{Findings}

By cultivating a learning community that emphasized that the youth researchers had valuable knowledge to share, we found that they chose to investigate topics that were of genuine interest to them and that were connected to their lives and histories. Students took up a range of issues, including Indonesian and Latino cultural practices, popular culture and new literacies, friendship, access to schooling, healthcare, and socioeconomic class as related to neighborhood concerns such as vandalism and food justice. In discussing community gardens, for instance, Regina commented that "what we grow [in community gardens] is expensive at the market" [Fieldnotes, Jan. 10, 2013]. While brainstorming research questions, one student wrote, "My other question is on the [neighborhood] community and it's about how people get treated because of how we look and our house and why they treat people with a certain kind of house that way" [Fieldnotes, Nov. 23, 2013]. Another prevalent theme of the youth's research was health care, in many cases motivated by family illnesses and difficulties in accessing adequate medical treatments. Students discussed with one another ailments suffered by loved ones: one participant shared that her mother had rheumatoid arthritis and her grandfather lung cancer; another had a younger sister who had been recently hospitalized. Importantly, the inquiries the students pursued did not necessarily address the topics we expected them to. For example, none of the students took up the issue of immigration, which affected their lives in very real ways. However, their inquiries into healthcare, friendship, neighborhoods, and other topics underscored the systemic issues they faced as well as their agency in interpreting and representing them. 
In the sections that follow, we highlight the inquiries of two of the Indonesian youth, Brian and Regina. At the time of our study, both Brian and Regina were in the seventh grade at charter schools that had the reputation of being "good school[s]" in the city [Interview, Jul. 20, 2014]. Their parents had learned about the school from friends and the news, and submitted an Intent to Enroll form to enter the admissions lottery. Brian, Regina, and their families viewed attending this school as a pathway to high school and college. At least one other participant in our study who attended the same charter school moved on to a Special Admission high school, commonly known as a "magnet school," with demanding admissions requirements based on standardized test scores and grades. Regina's two older siblings are now in college, one at a state college and one at a community college. Looking into the future, Regina was setting her sights on a variety of high schools she had heard of from family and friends. She noted, "I have a lot of options...I want to look deep in[to] them" [Interview, Jul. 20, 2014].

On the surface, these aspects of Brian's and Regina's stories seem to conform to the model minority stereotype: Asian-American parents push their children to excel in school, the student obtains a high GPA and high test scores, and then he or she is upwardly mobile and assimilates into mainstream society. We learned that this oversimplified narrative glosses over many issues and challenges, which the youth's research began to unearth.

\section{"Has a Doctor Ever Been Mistaken?": Brian's Inquiry Into Medicine and Bodily Fragility}

For Brian, who we met in the opening of this article, the Community Researchers Project provided a venue to investigate his interest in the sciences-in particular, medicine. It was also where he shared his first-hand experiences with health issues and the medical establishment. Brian was one of at least three participants whose interest in medicine grew out of personal struggles, including the language barriers and social precarity (Butler, 2011) faced by many new immigrants to the U.S. His research, which he compiled into a book titled "Surgery and Medicine" (Figure 1), investigated three research questions: 1) What are people's experiences with surgery?; 2) How does medicine affect the body and life of community members?; and 3) Has a doctor ever been mistaken about your body or diseases you had? This direction suggests that Brian's inquiry was not a disinterested investigation of the subject, but was tied to the medical experiences of community members and, we would later learn, of his own family. Brian's questions point to his concern for others' physical well-being, and to how individuals recognized as authorities on the subject could be fallible, an insight that one would be unlikely to find in informational books about medicine targeted to Brian's 
age group. It became evident in our review of the data that Brian was highly attuned to other's bodily fragility. While working on his questions, for example, he spoke about his teacher who had survived breast cancer; during this discussion, he also mentioned the relationship between stress and Parkinson's Disease [Fieldnotes, Feb. 2, 2014]. Later in the research process, he paused to ask several questions about cancer: "how it spreads, if one can survive it, and what the treatment process is like" [Fieldnotes, Jun. 1, 2014].

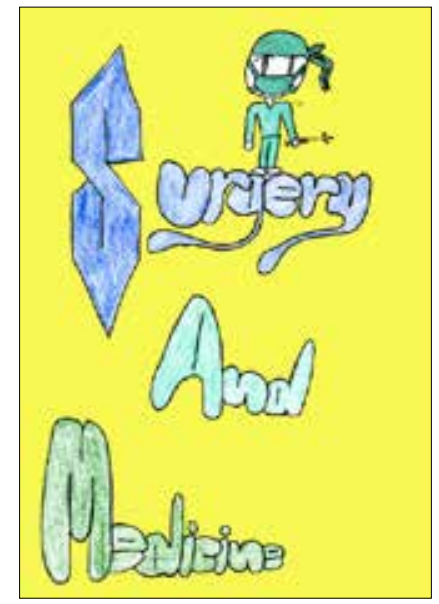

Fig. 1: "Surgery and medicine." This image is the cover of the book Brian created during the CRP.

Throughout the course of the inquiry and in an interview with Brian, we would learn about the personal experiences that fueled his interest in medicine. As a baby and young child, Brian underwent approximately 10 surgical operations for his hearing. In describing why he had decided to inquire into his chosen topic in the CRP, Brian wrote that, "surgery and medicine are important to me because I had experience [with] surgery and medicine for my ear/hearing" [Artifact, Feb. 2, 2014]. One important aspect of his medical ordeal was the lack of information Brian's family received about his condition and their difficulty in navigating healthcare due to language differences:

Brian: $\quad$...[The] doctor didn't like give like details to my mom about my hearing loss. He just said that um your baby can't hear from the left ear, but he could hear from the right ear, which confuses my mom because he - she couldn't speak English back then, but now she could, and um once I got older and I got the surgeries I could hear more better which is really um good for me because I could do piano lesson, um violin and all those stuff that I couldn't do before. [Interview, Jul. 20, 2014]

Although his family was eventually able to receive help and overcome the linguistic challenges, the process was nonetheless difficult:

Brian: When the doctor was talking to her [my mom] um she didn't know English, and um once the doctor was like speaking English like that uh she didn't uh understand. So she called my mom's friend which is an interpreter, and um 
the doctor was speaking to the interpreter, and then the interpreter was talking to my mom on the phone, and then my mom, she said that she was like really sad, and um she was praying for me every day, every time I have surgery and stuff like that. [Interview, Jul. 20, 2014]

We often hear statistics such as how in our city about $10 \%$ of the 1.4 million population are reportedly "Limited English Proficient" (Migration Policy Institute, 2013). Moreover, the myth of the model minority may lead to assumptions that a family like Brian's does not need linguistic or other supports. What these statistics and generalizations can obscure is the specifics of how language difference and cross-cultural misunderstanding, in a general climate of English Only monolingualism, impact a family's basic day-to-day affairs.

Brian's work also reflected his agency in drawing on social and cultural resources. For example, he recounts how his family enlisted the assistance of an interpreter from their community to navigate the healthcare system. Similarly, Brian invokes traditional medicinal remedies from his community in his research on diabetes, as seen in Figure 2.

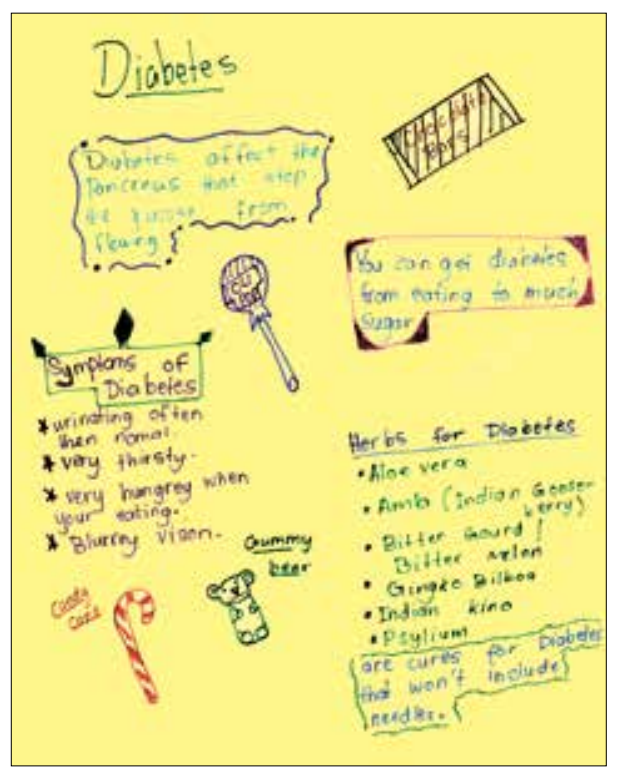

Fig. 2: Brian's research on diabetes

Through working with the Indonesian youth, we learned how herbal medicines co-existed with "Western" medicine in their lives. For example, one student had initially considered studying Eastern and Western medicine, and another student mentioned taking Chinese herbal medicines when she was ill. Likewise, Brian's cures for diabetes include culturally based remedies "that won't include needles." A number of students and their families gravitated towards these alternative remedies in part because they were less economically prohibitive. The issue of social class is one that would also become a theme in Regina's research. 


\section{"You Have Like Four People to Feed and 10 Dollars in Your Pocket": Regina's Inquiry Into Health Disparities}

Regina used her time at CRP to focus her inquiry on health issues, specifically asking, "Do people in my community exercise?" Regina surveyed members of her community to learn about their physical fitness (Figure 3), asking questions regarding the nature and frequency of their activities.

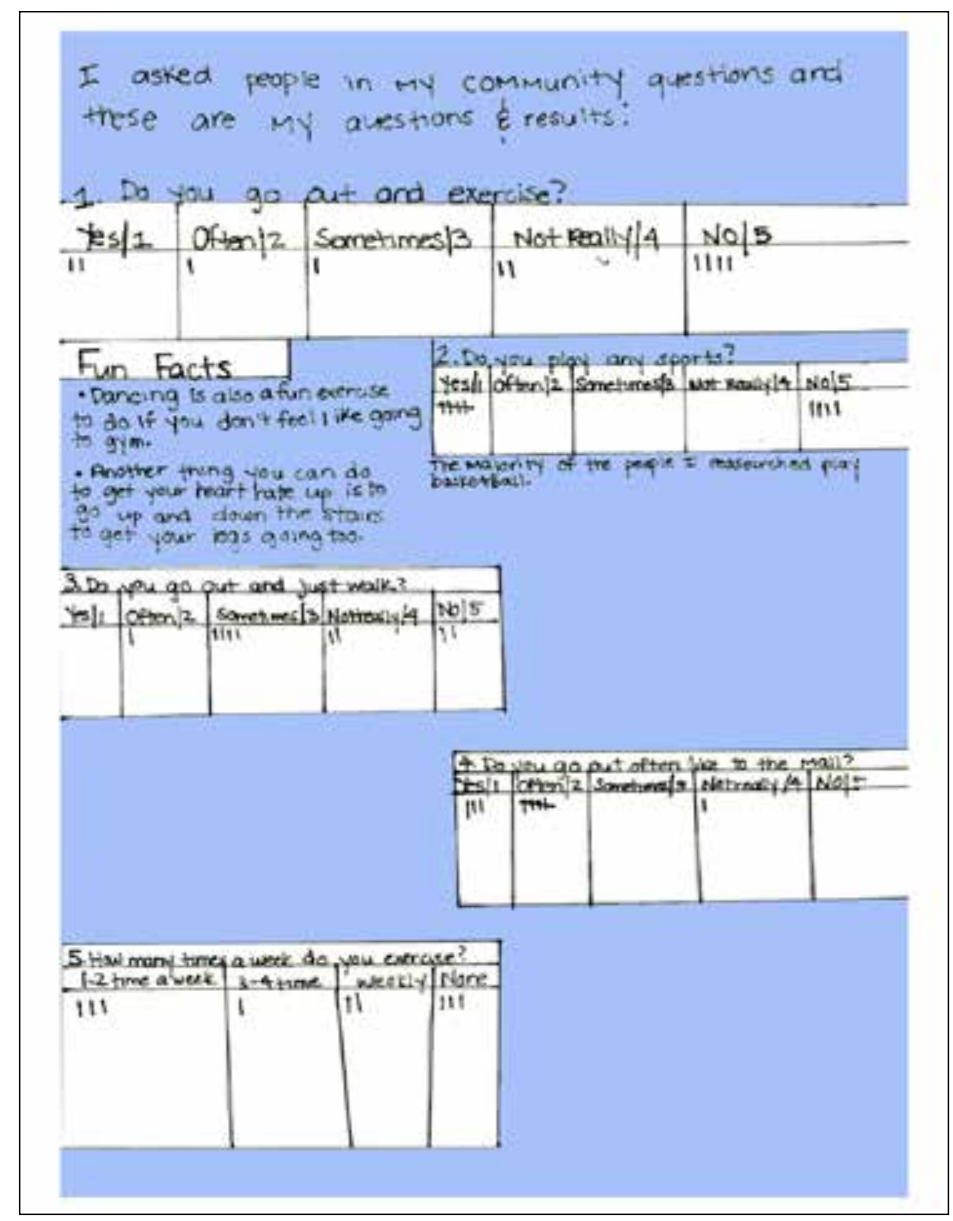

Fig. 3: Regina's survey questions

Regina's document also includes recommendations intended to change individual behaviors, such as dancing or taking the stairs. The implication is that with these fun and practical changes, people might overcome frequently cited obstacles to exercise and become healthier. 
As the research progressed, rather than locate blame on the individual, Regina began to gain critical consciousness about the conditions that lead to health disparities. In an interview about her project, Regina stated,

If I live in [neighborhood name] and [neighborhood name] has all these Burger Kings, McDonald's, Wendy's, all these other good places for cheap and stuff. Well, you could go to [market in a nearby neighborhood] and get vegetables and you know - but some days you don't want to spend a lot because you don't have a lot. You have like four people to feed, and you have like ten dollars in your pocket. So it's might as well you get something from McDonald's from the Dollar Menu, and you could get a lot of things, soft drinks and burgers and stuff, and that could affect of what you're eating and how you're living and that. [Interview, Jul. 20, 2014]

Regina noted how families in the area had limited access to healthy choices due to price and availability of fresh foods, and exposed the struggles her community faced when it comes to acquiring basic social goods. Her research led her to eventually identify her own neighborhood as a food desert.

It is important to note that Regina's story directly challenges some of the meritocratic ideologies that the model minority stereotype is designed to uphold. The model minority stereotype is often used to perpetuate ideas that "anyone can make it" in America, as the dominant view of Asians is one of immigrant success and prosperity (Lee, 2009). When immigrant and other minoritized communities don't "make it," a comparison is made to apparent Asian success, and failure to thrive is attributed to an individual's poor choices rather than to social conditions. Regina shows that it isn't for lack of trying that issues of health arise for poor communities. Rather, it is structural inequities that limit the possibilities for healthy choice. As she defies meritocratic ideologies in researching her experience, she also reveals the very inequities the stereotype is meant to hide.

\section{Tensions and Possibilities of Practitioner Research for Social Justice}

By providing a platform for Brian, Regina, and their peers to research their family and community, we were able to begin to better understand their experiences beyond a model minority stereotype. Brian, like many of the youth, developed a heightened sense of human vulnerability and fragility. Regina cultivated a critical awareness of 
the precarious social conditions that produce public health crises. These insights were born out of their experiences as racialized immigrants in the U.S. growing up in an under-resourced context. At the same time, they are developing the skills to analyze these systemic issues and cultivate activist identities that might eventually contribute to change.

We did find a number of tensions engaging in practitioner research with the Indonesian youth. Initially, we were wondering if the young people would employ the research opportunity to investigate immigrant rights, especially since it is an issue that had such immediate relevance to many of their families. Although the topic emerged in several peripheral conversations, it never became the focus of our work together. One possibility is that the immigration issues riveting the broader community were too traumatic to be taken up by the middle-school aged students. There are risks involved at research aimed toward social justice, and it is a priority for educators to protect the students from making themselves additionally vulnerable. No research methodology, including participatory varieties, can transcend the power asymmetries of a given context.

There were also several moments when we, as members of the research team, had to challenge some of the presuppositions we were bringing to the curriculum. For example, in order to be attentive to the youth's interest in medicine, we invited a dynamic and thoughtful medical doctor in the middle of his residency to share his ideas about the profession. At one point a number of the adults in the room discussed the importance of choosing to pursue work you love, since "you only live once." Reviewing our fieldnotes we realized that we may have been universalizing a particular cultural model (Gee, 2007) of work informed by our current privileged class status. For many in the community-who labor in low-wage service jobs-work was about survival and sacrifice for future generations, not necessarily self-actualization. And as we have discussed, even Brian, Regina, and their peers were motivated to examine health issues by an emerging sense of social responsibility. Just as we brought in outside experts, we might have also tapped the knowledge of community members, such as local leaders and everyday people, who navigated health and labor inequities and agitated for change.

One of the potential affordances of a practitioner research methodology, however, is the way it has built into it an internal feedback mechanism, whereby interpretation of the data emerging from practice and the multiple perspectives of participants in turn enables us to refine our conceptual lens and, with it, our future pedagogical decisions, a methodological process of "systematic improvisation" (Campano, 2007b). In response 
to what we were finding, for example, we helped organize a workshop on immigration for the St. Frances Cabrini community, where undocumented DREAMers from our university could share their experiences with the Indonesian and Latino youth. We also invited students from the Community Researchers Project to present their work as part of a Practitioner Inquiry conference hosted at our university, reversing the roles of who is considered an expert and whose knowledge is privileged. This systematic and rigorous process of mobilizing multiple perspectives and constantly interrogating one's own presuppositions helps us challenge reified categories that too often drive educational policy and practice. In this case, practitioner research helped unsettle model minority stereotypes and make visible the subaltern experiences of one community in our city. It also applies at the level of the individual, as each person's experiences are singular and can never be exhausted by the categories used to explain them. In this manner, practitioner research can both contest dominant ideologies of categorization and help create more humane and socially just learning communities that honor the complexity, nuance, and agency of all youth.

\section{Note}

1. There was an inadvertent lapse in IRB approval between $12 / 14 / 12$ and $6 / 22 / 15$, which was discovered and addressed in June 2015.

\section{References}

Alcoff, L. M. (2006). Visible identities: Race, gender, and the self. Oxford, UK: Oxford University Press.

Asian Americans Advancing Justice. (2013). A community of contrasts: Asian Americans, Native Americans and Pacific Islanders in the Northeast. Washington, DC: Author.

Ballenger, C. (2009). Puzzling moments, teachable moments: Practicing teacher research in urban classrooms. New York: Teachers College Press.

Butler, J. (2011, May 24). The precarious life: The obligations of proximity (potentiality of intercultural spaces). Lecture at Nobel Museum, Svenska Akademiens Börssal. Retrieved from: http://www.youtube.com/ watch?v=KJT69AQtDtg
Campano, G. (2007a). Honoring student stories. Educational Leadership, 65(2), 48-54.

Campano, G. (2007b). Immigrant students and literacy: Reading, writing, and remembering. New York: Teachers College Press.

Campano, G. (2009). Teacher research as a collective struggle for humanization. In $\mathrm{M}$. Cochran-Smith \& S. Lytle (Eds.), Inquiry as stance (pp. 326-341). New York: Teachers College Press.

Campano, G., \& Ghiso, M. P. (2011). Immigrant students as cosmopolitan intellectuals. In S. Wolf, P. Coates, P. Enciso, \& C. Jenkins (Eds.), Handbook on research on children's and young adult literature (pp. 164-176). Mahwah, NJ: Lawrence Erlbaum. 
Campano, G., Ghiso, M. P., Yee, M., \& Pantoja, A. (2013). Toward community research and coalitional literacy practices for educational justice. Language Arts, 90(5), 314-326.

Campano, G., Ghiso, M. P., \& Welch, B. (2015). Ethical and professional norms in community-based research. Harvard Educational Review 8(1), 29-49..

Cochran-Smith, M., \& Lytle, S. L. (1993). Inside/ Outside: Teacher research in communities. New York: Teachers College Press.

Cochran-Smith, M., \& Lytle, S. L. (2009). Inquiry as stance: Practitioner research for the next generation. New York: Teachers College Press.

Cunningham, C. E. (2008). Unity and diversity among Indonesian migrants to the United States. In H. Ling (Ed.), Emerging voices: Experiences of underrepresented Asian Americans (pp. 90-108). New Brunswick, NJ: Rutgers University Press.

Erickson, F. (1986). Qualitative methods in research on teaching. In $\mathrm{M}$. C. Wittrock (Ed.), Handbook of research on teaching (3rd ed., pp. 119-161). Thousand Oaks, CA: Sage Publications.

Gay, G. (2014). Culturally responsive teaching: Theory, research, and practice. New York: Teachers College Press.

Gee, J. (2007). Social linguistics and literacies: Ideologies in discourses. New York: Routledge.

Ghiso, M. P. (in press). The Laundromat as the transnational local: Young children's literacies of interdependence. Teachers College Record.

Ghiso, M. P., \& Campano, G. (2013). Coloniality in education: Negotiating discourses of immigration in schools and communities through border thinking. Equity and Excellence in Education, 46(2), 252-269.

Hune, S. (2000). Rethinking race: Paradigms and policy formation. In M. Zhou \& J. V. Lee, S. Lowe, L. (1996). Immigrant acts: On Asian American cultural politics. Durham, NC: Duke University Press.

Ichioka, Y. (Ed.). (1974). A buried past: An annotated bibliography of the Japanese research project collection. Oakland, CA: University of California Press.
Lee, S. J. (2009). Unraveling the "model minority" stereotype: Listening to Asian American youth (2nd ed.). New York: Teachers College Press.

Lee, S. S-H. (2014). A new history of Asia America. New York: Routledge.

Lowe, L. (1996). Immigrant acts: On Asian American cultural politics. Durham, NC: Duke University Press.

Migration Policy Institute. (2013). Tabulations from the US Census Bureau's pooled 20092011 American Community Survey (for the United States and states, except Wyoming and Puerto Rico) and 2007-2011 ACS (for counties, plus Wyoming and Puerto Rico). Retrieved from: http://www.lep.gov/demog_data/ demog_data.html

Moya, P. (2002). Learning from experience: Minority identities, multicultural struggles. Berkeley: University of California Press.

Museus, S.D., \& Kiang, P. N. (2009). Deconstructing the model minority myth and how it contributes to the invisible minority reality in higher education research. New Directions for Institutional Research, 142, 5-15.

Ngo, B., \& Lee, S. J. (2007). Complicating the image of model minority success: A review of Southeast Asian American education. Review of Educational Research, 77(4), 415-453.

Strauss, A., \& Corbin, J. (1998). Basics of qualitative research: Grounded theory procedures and techniques. Newbury Park, CA: Sage.

U.S. Census Bureau. (2011). 2006-2010 American community survey 5-year estimates. Washington, DC: Author. Retrieved from: http://www.census.gov/acs/www/data _documentation/2010_release/

U.S. Census Bureau. (2012). The Asian population: 2010, Census 2010 brief. Washington, DC: Author. Retrieved from: http://www.census. gov/prod/cen2010/briefs/c2010br-11.pdf

Vasquez, V. (2004). Negotiating critical inquiries with young children. Mahwah, NJ: Lawrence Erlbaum. 


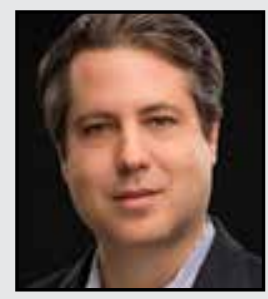

Gerald Campano is Associate Professor and Chair of the Reading/Writing/Literacy Division at the University of Pennsylvania's Graduate School of Education. His scholarship focuses on practitioner research, immigrant students and families, critical literacy, identity, and university-community partnerships. Gerald has been a full-time classroom teacher in Houston, Puerto Rico, and California, and has garnered numerous teaching awards at the elementary and university level. Gerald is a Carnegie Scholar and the recipient of the David H. Russell Award for Distinguished Research in the Teaching of English from NCTE for his book Immigrant Students and Literacy: Reading, Writing, and Remembering.

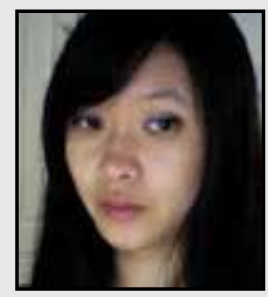

Lan Ngo earned her PhD at the University of Pennsylvania Graduate School of Education. She has taught English as another language in the U.S. and Japan. Her research interests concern the language and literacy practices of linguistically and culturally diverse, school-aged learners in the U.S. Her dissertation examines language and literacy access as an issue of equity and as a means to increase the life chances of traditionally marginalized students. Specifically, she studied the learning experiences and contexts of immigrant and refugee students in content area classrooms in an urban public high school, and offers recommendations to teachers, school administrators, and researchers regarding how to better work with English language learners.



Grace Player is a former elementary school teacher who has taught in New York, Connecticut, and Japan and has also conducted literacy professional development across the country. She is currently a PhD student at the University of Pennsylvania's Graduate School of Education in the Reading/ Writing/Literacy program. Her emerging research interests are focused on feminist writing spaces for young girls of color. 